\title{
EFEKTIFITAS PENGGUNAAN UMPAN PADA BUBU DASAR (BOTTOM FISH POTS) DI PERAIRAN PULAU BUNYU KALIMANTAN UTARA
}

\section{THE EFFECTIVENESS OF BAIT IN BASIC BUBU (BOTTOM FISH POTS) IN THE WATERS OF BUNYU ISLAND, NORTH KALIMANTAN}

\author{
Muhammad Firdaus ${ }^{1)}$, Dhimas Wiharyanto ${ }^{2)}$, Gazali Salim ${ }^{3)}$ \\ 1,2,3) Jurusan Manajemen Sumberdaya Perairan, Fakultas Perikanan dan IImu Kelautan \\ Universitas Borneo Tarakan \\ Jalan Amal Lama Nomor 1, Tarakan \\ Email: ${ }^{1}$ dayax2302@yahoo.com
}

\begin{abstract}
ABSTRAK
Wilayah pulau Bunyu merupakan bagian dari area administrasi Kabupaten Bulungan, sebagai wilayah yang memiliki potensi perikanan yang menjanjikan. Sebagaian besar masyarakat pulau Bunyu bekerja sebagai nelayan dengan menggunakan bubu tanpa umpan. Penelitian ini bertujuan meningkatkan efektifitas penangkapan ikan, dengan menambahkan umpan ikan rucah pada alat tangkap bubu. Penelitian menggunakan metode sampling bertujuan tertentu dan percobaan penangkapan. Alat tangkap bubu dipasang di perairan pulau Bunyu dengan menggunakan umpan dan tidak menggunakan umpan setiap 3 hari sekali. Hasil penelitian menunjukkan bahwa jenis ikan yang tertarik sebagai ikan demersal adalah ikan kakap merah (Lutjanus erythropterus), ikan kakap gigi anjing (Lutjanus jocu), ikan kerapu lumpur (Epinephalus coloides) dan ikan kakap jenaha (Lutjanus russelli). Total hasil tangkapan pada bubu menggunakan umpan $100 \%$ efektifitas menangkap ikan dengan total berat $218,33 \mathrm{~kg}$ dan bubu tanpa umpan total berat $152,77 \mathrm{~kg}$ dengan $80 \%$ efektifitas menangkap ikan. Hasil yang diperoleh bahwa penggunaan umpan lebih efektif dibadingkan tanpa menggunakan umpan pada pengoperasian bubu di perairan Bunyu.
\end{abstract}

\section{Kata Kunci : Efektifitas; Hasil Tangkapan; Ikan Demersal; Ikan Kakap; Perairan Bunyu}

\begin{abstract}
The territory of the islands of Bunyu is part of the Bulungan administrative area, as a territory of the sea that has the potential fisheries who promised. Most of the Bunyu islands people's work as captured fishermen with fishing the bottom fish pots without bait. The research was aimed at increasing the effectiveness of the catch of fish, by adding trash fish bait to the bottom fish pots. The study used a purposive sampling method and experimental fishing. Bottom fish pots installed in the waters is calculated by catch using bait and does not use bait every 3 days. The results showed that the types of fish attract as demersal fish are Red Snapper (Lutjanus erythropterus), Dog Snapper (Lutjanus Jocu), Grouper (Epinephelus Coioides), Jenaha Snapper (Lutjanus Russelli). Total number of used a bait with $100 \%$ catch effectiveness fish with total weigth of $218,327 \mathrm{~kg}$ and do not used a bait with a total weight of $152,774 \mathrm{~kg}$ with the effectiveness of catching $80 \%$. So the results obtained using bait are more effective than not using bait of bottom fish pots in Bunyu waters.
\end{abstract} Keywords: Effectiveness; Fishing Catch; Demersal Of Fish; Snapper Fish; Bunyu
Waters

\section{PENDAHULUAN}

Pulau Bunyu adalah sebuah kecamatan

di Kabupaten Bulungan, Provinsi
Kalimantan Utara, Indonesia. Kecamatan ini memiliki karateristik pulau kecil dengan 
JURNAL BORNEO SAINTEK

Volume 2, Nomor 2, Oktober 2019

e-ISSN 2599-3313

p-ISSN 2615-434X

luas wilayah 198,32 km². Pulau Bunyu merupakan bagian wilayah administrasi Provinsi Kalimantan Utara yang dikelilingi lautan dengan potensi perikanan yang terindikasi sangat potensial. Salah satu potensi perikananya adalah perikanan tangkap. Sebagian besar masyarakat Pulau Bunyu berprofesi sebagai nelayan. Jumlah masyarakat yang berprofesi sebagai nelayan dipulau bunyu diperkirakan kurang lebih sekitar 122 nelayan yang aktif saat ini dengan berbagai alat tangkap yang mereka gunakan pada saat mencari ikan. Alat tangkap yang mereka gunakan yakni trawl, pancing, rawai, rengge, bubu. Sebagian besar nelayan di pulau bunyu menggunakan alat tangkap bubu.

Alat tangkap bubu yang digunakan nelayan di perairan bunyu sangat ramah lingkungan bahan yang digunakan terbuat dari bambu yang di anyam sedemikian rupa untuk menjebak ikan masuk kedalam alat tangkap dan tidak dapat keluar. Hasil survei pendahuluan yang dilakukan diketahui bahwa tidak satupun nelayan
Available online at www.jurnal.borneo.ac.id Halaman 11-17

yang menggunakan umpan dalam proses penangkapan ikan dengan alat tangkap bubu. Nelayan bubu di Pulau Bunyu dalam pengoperasiannya hanya meletakkan bubu di perairan lalu meninggalkannya. Setelah beberapa hari (kisaran 2 - 4 hari), nelayan kembali ke perairan dan mengangkat bubu untuk mengambil hasil tangkapan yang kemudian jika bubu tersebut tidak rusak nelayan meletakkan kembali ke perairan.

Menurut Sudirman dan Mallawa (2004), bubu merupakan alat tangkap yang pengoperasianya diletakan atau dipasang dalam air untuk mem udahkan ikan atau target tangkapan masuk kedalam bubu dan menyulitkan ikan untuk keluar dari bubu. Sedangkan menurut Ambarsari (2014), alat ini biasanya dibuat dari bahan alami, seperti bambu, kayu, atau bahan buatan lainya seperti jaring. Alat tangkap bubu termasuk dalam jenis perangkap atau jebakan yang ditambahkan umpan sebagai faktor menunjang keberhasilan operasi penangkapan.

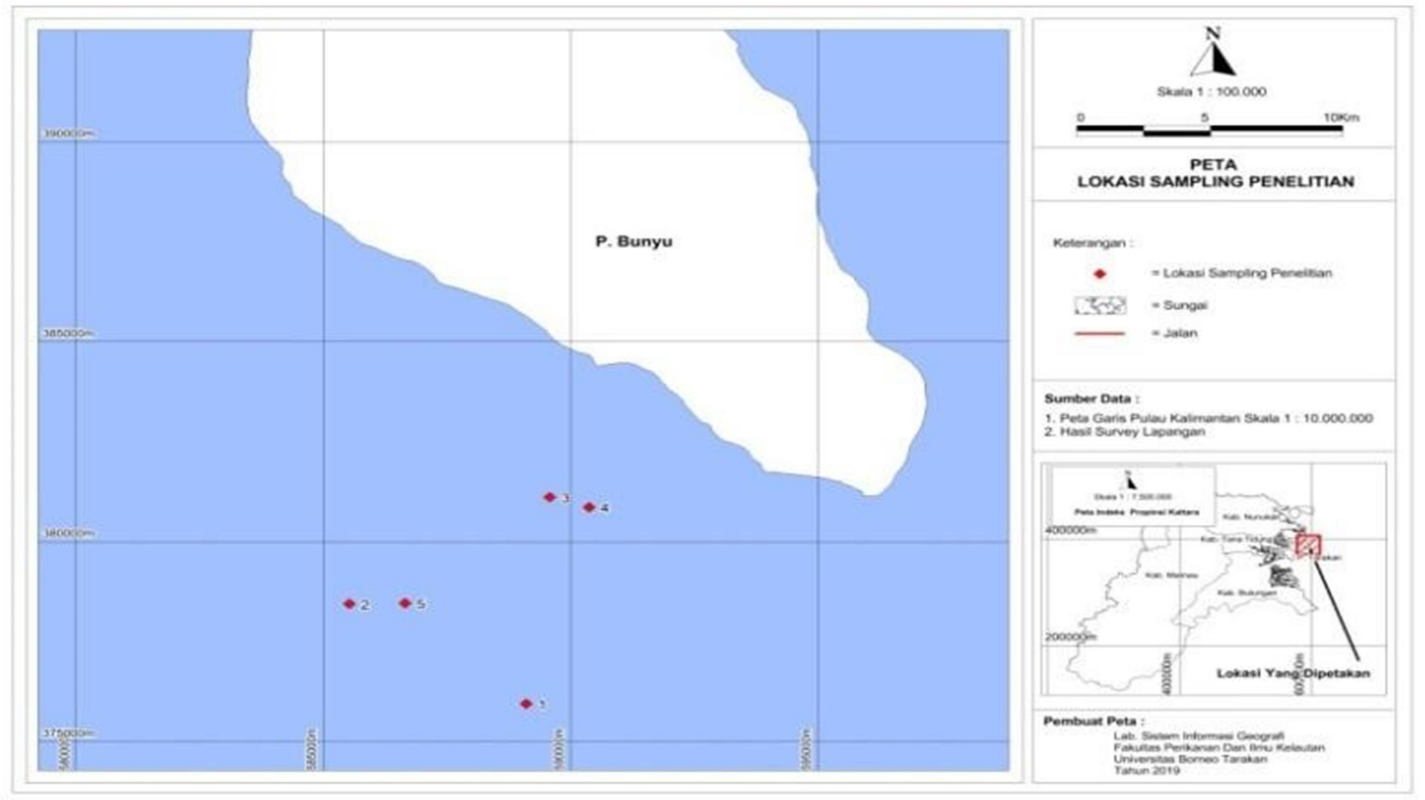

Gambar1. Peta lokasi pengambilan sampel

Pada penelitian kali ini alat tangkap bubu yang biasanya digunakan nelayan tidak memakai umpan akan ditambahkan umpan yang bermaksud agar jumlah efektifitas tangkapan bisa bertambah jika dengan adanya umpan sebagai pemikat ikan masuk dan terjebak pada alat tangkap bubu tersebut. Selain umpan 
dalam pengoperasian bubu juga memerlukan pengetahuan dan pengalaman nelayan berkenaan dengan waktu dan tempat penangkapan (fishing ground), juga memerlukan alat atau bahan penangkapan tambahan yang mampu mendukung atau meningkatkan hasil tangkapan.

Penggunaan umpan dalam pengoperasian alat tangkap dalam menangkap sumberdaya ikan merupakan salah satu faktor yang penting dalam keberhasilan penangkapan. Hal yang harus diperhatikan dalam penggunaan umpan adalah jenis ikan yang dipergunakan sebagai umpan, penempatan umpan pada alat tangkap bubu, bentuk dan ukuran umpan. Mengetahui jenis umpan, ukuran dan tata penempatan umpan, akan memperbesar respon ikan tangkapan terhadap umpan yang akan masuk ke dalam bubu. Terindikasi bahwa terdapat hubungan yang signifikan antara penggunaan umpan terhadap hasil tangkapan, karena umpan sebagai alat bantu perangsang yang mampu memikat sasaran penangkapan dan meningkatkan efektifitas penangkapan (Kamelia 2008).

Peningkatan efektifitas penangkapan pada pengoperasian bubu di perairan Bunyu, sangat diperlukan untuk meningkatkan kesejahteraan nelayan Pulau Bunyu. Salah satu upaya dengan pengunaan umpan diduga mampu meningkatkan efektifitas penangkapan ikan pada perikanan bubu. Penggunaan umpan yang tepat dari variabel jenis, ukuran, bentuk dan tata penempatan akan menjadi dasar pemikiran dalam upaya peningkatan efektifitas pengoperasian bubu dengan hasil tangkapan ikan-ikan yang bernilai ekonomis tinggi yang menjadi target utama pada alat tangkap bubu di perairan selatan Pulau Bunyu.

METODE PENELITIAN
Penelitian dilakukan di perairan Selatan Pulau Bunyu (gambar 1). Perairan tersebut merupakan daerah pengoperasian perikanan bubu oleh nelayan Pulau Bunyu. Penelitian akan dilakukan selama 3 (tiga) bulan mulai dari bulan Agustus sampai dengan Oktober 2018. Lokasi penelitian dilakukan di perairan Barat Pulau Bunyu, dimana perairan ini merupakan lokasi yang digunakan nelayan sebagai daerah penangkapan ikan (fishing ground) dengan alat tangkap bubu. Penentuan titik lokasi sampling ditetapkan oleh peneliti secara acak (random sampling) sebanyak 5 titik sampling. Perairan sebagai fishing ground merupakan suatu tempat yang lokasinya secara ekonomis menguntungkan dan tidak jauh dari tempat pendaratan ikan (Nomura, 1977).

Alat yang digunakan dalam penelitian ini sebagai berikut adalah:, Global Positioning System (GPS), Kalkulator, Penggaris, Timbangan Analitik, Kamera, Alat Tulis, Alat Tangkap Bubu, Perahu, Tali dan Pemberat, Keranjang, Buku Identifikasi Ikan. Bahan yang digunakan dalam penelitian ini sebagai berikut adalah: Umpan ikan rucah, Ikan hasil tangkapan.

Teknik operasi penangkapan dengan alat tangkap bubu dibagi menjadi 5 tahap yakni tahap persiapan, penentuan daerah penangkapan (fishing ground), penurunan alat tangkap (setting), perendaman alat tangkap (soaking) dan pengangkatan alat tangkap (hauling). Tahap persiapan dilakukan sebelum melakukan operasi penangkapan meliputi: pemeriksaan mesin, pengisian bahan bakar, dan persiapan dua pasang alat tangkap bubu yang sudah diberi umpan dan tanpa umpan. Penentuan daerah penangkapan pada lokasi yang telah ditetapkan sebelumnya yaitu pada titik koordinat berdasarkan kegiatan survey pendahuluan.

Setting alat tangkap bubu dilakukan dengan bantuan nelayan yang biasa beroperasi di perairan pulau bunyu. 
Setting dilakukan pada titik sampling 1 pada pagi hari pukul 07.00 diawali dengan penurunan alat tangkap yang sudah disiapkan dengan perlakuan satu alat tangkap bubu dipasangi umpan dan satu alat tangkap bubu yang tidak diberi umpan secara lengkap dengan diikat tali dan diberi pemberat agar tidak terbawa arus lalu diturunkan kedasar laut. Lama setting berkisar 15 - 20 menit dengan setiap bubu di beri jarak 10 meter dengan kedalaman perairan sekitar 20 meter.

Proses soaking pada penelitian ini dilakukan dalam 3 hari (72 jam). Waktu rendaman alat tangkap (soaking time) berdasarkan pada ketentuan dimana pada kondisi real dilapang, para nelayan meletakkan bubu paling cepat 2 hari ( 48 jam) dan paling lama selama 4 hari (96 jam), sehingga pada penelitian ini ditetapkan waktu tengah antara 2 hari dan 4 hari yaitu 3 hari atau ( 72 jam).

Tahapan pengangkatan alat tangkap (hauling) dilakukan setelah 3 hari perendaman alat tangkap bubu. Pada proses hauling dilakukan juga pengambilan, pencatatan dan pengukuran hasil tangkapan baik pada bubu yang diberi umpan maupun bubu tanpa umpan. Setelah proses hauling selesai (20 - 30 menit) dilanjutkan pada penurunan alat tangkap bubu (umpan dan tanpa umpan) pada lokasi/ titik sampling II. Demikian seterusnya tahapan pengoperasian bubu hingga lokasi / titik sampling V.

Tahapan pengoperasian bubu pada penelitian ini diulang sebanyak 2 kali, sehingga total waktu pengumpulan data adalah 30 hari (1 bulan) dengan data yang terkumpul dari 10 unit bubu sebanyak 20 satuan data (10 satuan data bubu umpan dan 10 satuan data bubu tanpa umpan). Data yang akan dikumpulkan meliputi data hasil tangkapan dari pengoperasian bubu dan data lingkungan perairan. Data hasil tangkapan (umpan dan tanpa umpan) dari ikan yang tertangkap yaitu: jenis ikan, jumlah (per spesies dan total), ukuran (panjang total, spesies/ekor dan berat spesies/ekor).

Efektifitas hasil tangkapan yaitu kemampuan dari alat tangkap bubu untuk menangkap ikan dengan membandingkan hasil tangkapan dengan jumlah alat tangkap bubu dari tiap perlakuan. Metode yang ditujukkan untuk mengukur efektivitas penggunaan umpan pada bubu untuk menangkap ikan kerapu (Ef), yaitu banyaknya bubu yang menangkap ikan dengan menggunakan umpan dibandingkan dengan total bubu yang digunakan (TB) dinyatakan dalam persen (Rochmawati,

$$
E f=\frac{K u}{T B} \times 100
$$

Keterangan:

$$
\begin{aligned}
& \mathrm{Ef} \quad=\text { Efektifitas Penangkapan Bubu } \\
& \mathrm{Ku} \quad=\text { Banyaknya Bubu yang Menangkap Ikan (Umpan) } \\
& \mathrm{TB}=\text { Total Bubu yang Digunakan }
\end{aligned}
$$

\section{HASIL DAN PEMBAHASAN}

Pulau Bunyu merupakan wilayah yang dikelilingi oleh lautan, sehingga banyak masyarakat yang melakukan penangkapan ikan diantaranya dengan menggunakan alat tangkap bubu. Daerah penangkapan memiliki kedalaman $\pm 15-25 \mathrm{~m}$ daerah penangkapan diduga bersubtrat lumpur berpasir yang cocok untuk tempat tinggal ikan. Menurut Badrudin dan Karyana (1992) bahwa nelayan biasanya mengoperasikan alat tangkap bubu pada kedalaman $20 \mathrm{~m}$. Lebih lanjut Meldiani (2007) bahwa daerah penangkapan alat tangkap bubu adalah perairan yang mempunyai dasar perairanya berlumpur maupun berpasir atau daerah berkarang, tergantung ikan, yang menjadi target tangkapan utama. 
Keadaan cuaca dan kondisi Laut (musim, arus dan gelombang) yang juga menentukan keberhasilan alat tangkap bubu maka hal ini juga perlu dipertimbangkan saat akan melakukan kegiatan penangkapan di perairan ini. Pada saat penangkapan ikan diarea utara pulau bunyu pada bulan September hingga oktober perairan tidak begitu tenang, adanya gelombang tetapi tidak begitu besar dan angin bertiup sangat kencang. Sesuai dalam Rachman (2009) mengemukakan bahwa suatu perairan dapat dikatakan daerah penangkapan ikan (fishing ground) dari suatu alat tangkap jika faktor oceanografi di perairan tersebut telah diketahui.

Efektifitas hasil tangkapan yaitu kemampuan dari alat tangkap bubu untuk menangkap ikan dengan membandingkan hasil tangkapan dengan jumlah alat tangkap bubu dari tiap perlakuan. Nilai efektivitas rata-rata hasil tangkapan bubu pada tiap perlakuan mempunyai nilai efektivitas berkisar 10 - 14.4. Nilai efektifitas tiap perlakuan selengkapnya dapat dilihat pada (Gambar 2).

Berdasarkan jumlah hasil tangkapan bubu pada tiap perlakuan yang digunakan pada saat penelitian maka alat tangkap yang memiliki umpan berhasil 100\% dibandingkan alat tangkap yang tidak memiliki umpan yang keberhasilanya hanya $80 \%$ dari jumlah keseluruhan alat tangkap yang digunakan. Nilai efektifitas alat tangkap yang berhasil menangkap ikan pada perlakuan penggunaan umpan lebih besar dibandingkan dengan perlakuan tanpa menggunakan umpan (Gambar 2 dan Tabel 1).

Alat tangkap bubu menggunakan umpan mempunyai nilai efektifitas yang tinggi di atas rata-rata yaitu pada stasiun 1, 4 dan 5. Nilai efektifitas tangkapan bubu rata - rata adalah sebesar 14.0. Nilai tersebut diketahui dari nilai rata- rata pada nilai efektifitas setiap stasiun. Nilai efektifitas terendah dibawah ratarata pada stasiun 2 dan 3.

Alat tangkap yang tidak menggunakan umpan mempunyai nilai efektifitas yang tinggi diatas rata-rata yaitu pada stasiun 1, 3 dan 5. Nilai efektifitas tangkapan bubu pada perlakuan tanpa umpan rata - rata adalah sebesar 10.0. Nilai tersebut diketahui dari nilai rata- rata pada nilai efektifitas setiap stasiun. Efektifitas terendah dibawah rata-rata yaitu pada stasiun 2 dan 4. Selanjutnya dapat kita lihat pada stasiun 5 efektifitas penangkapan juga hampir sama pada tiap perlakuan. Nilai efektifitas menggunakan umpan memiliki nilai lebih besar dibandingkan dengan alat tangkap yang tidak menggunakan umpan.

Jumlah alat tangkap bubu yang menggunakan umpan lebih dominan mendapat ikan dibandingkan tidak menggunakan umpan. Stasiun 3 memiliki efektifitas tangkapan berbanding terbalik yang tidak menggunakan umpan yang dominan lebih tinggi dibandingkan menggunakan umpan. Kemungkinan faktor lokasi dan kondisi perairan pada saat itu yang mempengaruhi penangkapan pada tiap stasiun yang menyebabkan nilai efektifitas hasil tangkapan yang berbeda.

Menurut (Ferno, 1986) respon ikan dipengaruhi baik oleh arus lemah maupun arus kuat pada lokasi, menunjukan bahwa aktivitas ikan lebih besar pada saat berarus daripada tidak berarus. Namun keberhasilan alat tangkap bubu sangat bergantung pada tingkah laku hewan laut yang menjadi target penangkapan kemudian ukuran alat tangkap yang bertindak sebagai fishing function; dimana hewan laut tersebut dapat masuk dan meloloskan diri.

Adapun nilai efektifitas rata-rata pada hasil tangkapan bubuyang diperoleh dengan perlakuan umpan yaitu 14,4 dan yang tidak menggunakan umpan 10 yang menunjukan bahwa kemampuan dari alat tangkap bubu untuk menangkap ikan dengan menggunakan umpan rata-rata sebesar $100 \%$ dan yang tidak menggunakan umpan sebesar $80 \%$. Secara visual rata-rata dari kedua perlakuan menunjukan kemampuan alat tangkap bubu untuk menangkap ikan berbeda secara nyata. Dari keseluruhan hasil tangkapan bubu pada tiap perlakuan ikan-ikan yang diperoleh ialah ikan ekonomis penting. Hal ini diperkirakan umpan rucah mempunyai kelebihan yang disukai ikan target yakni dengan mudah dapat melihat umpan pada jarak yang jauh serta tahan didalam air. Selain itu umpan ini mempunyai bau yang cukup tajam 
JURNAL BORNEO SAINTEK

Volume 2, Nomor 2, Oktober 2019

e-ISSN 2599-3313

p-ISSN 2615-434X

sehingga merangsang indera penciuman ikan. Kuat atau kurangnya rangsangan atau stimulasi kedua indera penglihatan dan penciuman akan mempengaruhi rangsangan terhadap nafsu makan ikan.

Hasil tangkapan ikan bubu di perairan utara pulau bunyu selama penelitian dengan menggunakan umpan memperoleh lebih banyak ikan ekonomis tinggi dibandingkan alat tangkap yang tidak memiliki umpan. Ikan hasil tangkapanya memiliki nilai ekonomis tinggi yang merupakan target utama nelayan bubu sebab telah memberikan keuntungan bagi nelayan, selain itu keberadaan ikan rucah
Available online at www.jurnal.borneo.ac.id

Halaman 11-17 relatif mudah diperoleh dalam jumlah yang cukup untuk dijadikan umpan, ikan ini tidak mudah busuk, dan sesuai dengan persyaratan yang harus dipenuhi umpan secara teknis maupun ekonomis (Santoso, 1995).

Lebih lanjut Zulkarnaen et al. (2011) tingginya nilai ekonomi ikan yang menjadi pendorong nelayan untuk menangkapnya walaupun jumlah tangkapan sedikit namun berkualitas maka nelayan mendapatkan penghasilan yang tinggi. Oleh karena itu, nilai efektifitas penangkapan di hitung berdasarkan berat total hasil tangkapan.

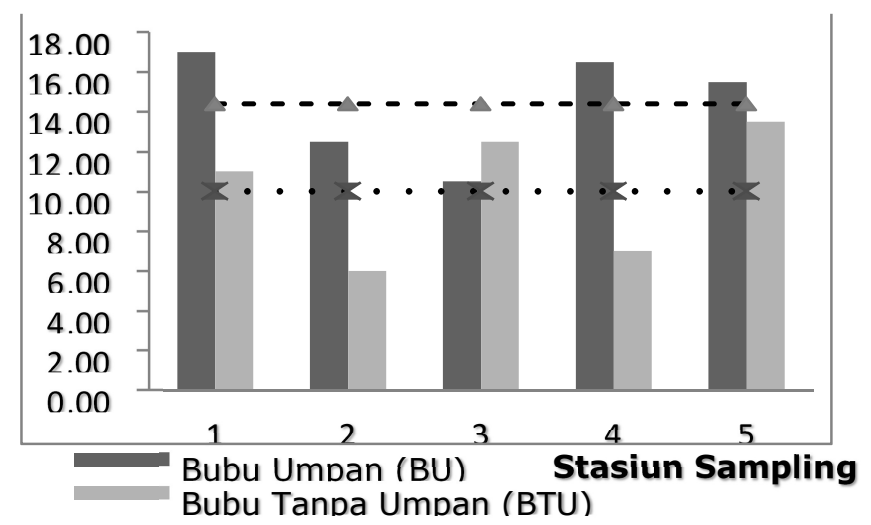

Gambar 2. Nilai Efektifitas Tiap Stasiun Sampling pada Tiap Perlakuan

Tabel 1. Nilai Efektifitas Alat Tangkap yang Mendapat Ikan

\begin{tabular}{|c|c|c|}
\hline \multicolumn{3}{|c|}{ Umpan } \\
\hline $\boldsymbol{\Sigma}$ total bubu (TB) & $\boldsymbol{\Sigma}$ bubu ikan (BI) & Ef \\
\hline 10 & 10 & 100 \\
\hline \multicolumn{2}{|c|}{ Tanpa Umpan } \\
\hline $\boldsymbol{\Sigma}$ total bubu (TB) & $\boldsymbol{\Sigma}$ bubu ikan (BI) & Ef \\
\hline 10 & 8 & 80 \\
\hline
\end{tabular}

\section{KESIMPULAN}

Komposisi hasil tangkapan bubu di perairan selatan pulau Bunyu dengan perlakuan menggunakan umpan dan tidak menggunakan umpan seluruhnya berjumlah 244 ekor ikan dengan berat total $371,010 \mathrm{~kg}$. Terdiri dari 4 jenis ikan yaitu: Kakap merah (Lutjanus erythropterus), KakapAnjing (Lutjanus Jocu), Kerapu (Epinephelus coioides), Jenaha (Lutjanus Russelli). Hasil tangkapan menggunakan umpan lebih efektif dalam menangkap ikan dengan keseluruhan hasil tangkapan berjumlah 144 ekor ikan dengan berat total 218,327 kg. Nilai efektifitas rata-rata 14,4 dengan keberhasilan alat tangkap menangkap ikan sebesar $100 \%$ dari keseluruhan jumlah alat tangkap. Hasil tangkapan tidak menggunakan umpan seluruhnya berjumlah 100 ekor ikan dengan berat total $152,774 \mathrm{~kg}$, Nilai efektifitas rata-rata 10 dengan keberhasilan alat tangkap menangkap ikan sebesar $80 \%$ dari jumlah keseluruhan jumlah alat tangkap.

\section{DAFTAR PUSTAKA}

Ambarsari, A. A. (2014). Pengaruh Umpan Yang Berbeda Pada Pengoperasian 
Bubu Terhadap hasil Tangkap Rajungan (Portunus sp) di Perairan Kabupaten Lamongan, Jawa Timur. Skripsi Sarjana. Fakultas Perikanan Dan Ilmu Kelautan. Universitas Brawijaya, Malang.

Badrudin, M dan Karyana. (1992). Indek Kelimpahan Stok Sumberdaya Ikan Demersal di Perairan Pantai Barat Kalimantan. Jurnal Penelitian Perikanan Laut (71) Tahun (1992), BPPL. Jakarta.

Ferno A, Olsen S. (1994). Marine Fish Behaviour in Capture and Abudance Estimation, Fishing News Books, England. Pp: 221

Firdaus A Olsen S. (1994). Kajian Fishing Gear Serta Metode Pengoperasian Rawai (Long Line) Di Perairan Bagian Selatan Pulau Tarakan. Jurnal Harpodon Borneo, 4(1)

Karyana, (1992). Indek kelimpahan Stok Sumberdaya Ikan Demersal di Perairan Pantai Barat Kalimantan,
Jurnal Penelitian Perikanan Laut No.71 BPPL: Jakarta.

Nomura, M. T. Yamazaki. (1977). Fishing Technique 1. Japan Internasional Cooperation Agency, 206. Tokyo.

Rachman, Maman. (2008). Penelitian Tindakan Kelas (Dalon Bagan). Semarang: Universitas Negeri Semarang.

Santoso. A, dan Susilo. E. S. (1995). Studi Pendahuluan Hubungan Panjang Berat Ikan Tenggiri (Scomberomorus Commerson) Dari Perairan Semarang. Jurnal Kelautan Tropis. Vol 19. Hal 161- 165

Sudirman dan Mallawa, A. (2004). Teknik Penangkapan Ikan. Jakarta: Rineka Cipta.

Zulkarnaen, Baskoro, M.S., Martasuganda, S. dan Monintja, D (2011). Pengembangan Desain Bubu Lobster yang Efektif Buletin PSP. Vol, XIX, (2): Hal 45-57. 
